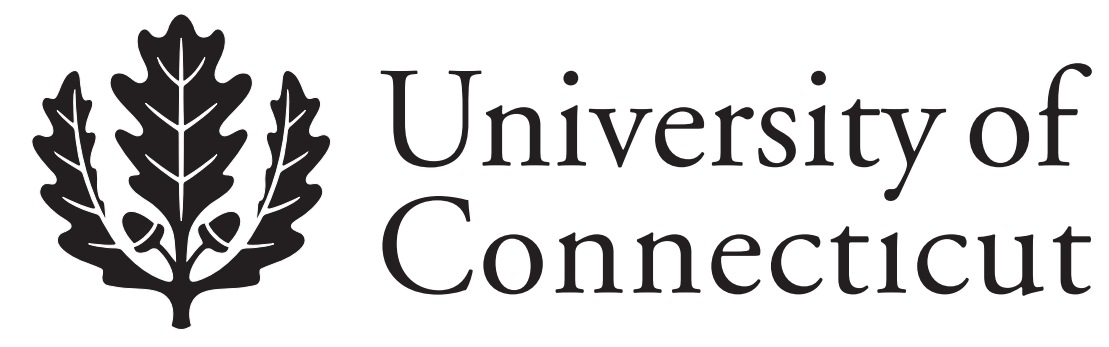

Department of Economics Working Paper Series

\title{
An Economic Analysis of Drawing Lines in the Sea
}

Paul Hallwood

University of Connecticut

Working Paper 2007-21

May 2007

341 Mansfield Road, Unit 1063

Storrs, CT 06269-1063

Phone: (860) 486-3022

Fax: (860) 486-4463

http://www.econ.uconn.edu/

This working paper is indexed on RePEc, http://repec.org/ 


\begin{abstract}
It is shown that low dispute costs relative to expected resource rents from oceanic resources favor drawn out disputes over maritime boundaries; asymmetric dispute costs favor agreement on boundaries wanted by the low dispute cost state party; and high symmetric dispute costs favor formation of joint development zones. The fact that most maritime boundaries have not yet been drawn suggests that state parties think that resource rents that can be drawn from the oceans are high relative to dispute costs. Moreover, the recent mini-trend towards JDZs in East Asia suggests that state parties in the area have recently reassessed dispute costs as being higher than previously believed.
\end{abstract}

Journal of Economic Literature Classification: F51, Q22, Q58

Keywords: Law of the Sea, joint development zones, maritime boundaries, marine boundaries, lines in the sea 


\section{I: Introduction}

Agreement on maritime boundaries is proving to be drawn out and fractious. Of 430 potential maritime boundaries only 210 have been agreed, 49 percent of the total - a percentage that overstates progress as potential boundaries between islets in the South China Sea are not included in this figure, and disputed islands are treated as belonging to the state that currently occupies them. Moreover, boundary agreements often do not cover all jurisdictional issues - for example, fisheries management and delimitation of the continental shelf. Agreements may also not cover the full length of a potential boundary. ${ }^{1}$

A 'state of nature' (no agreed laws) rather than a 'civil society' exists in disputed ocean space. Economic theory suggests that in the absence of property rights resources will be over-exploited and resource rents dissipated - for which in the case of fisheries there is much evidence (see Myers and Worm, 2003, who record that industrial fishing has significantly reduced fish stocks by as much as 90 percent of their levels of 50 years earlier). Moreover, as Demsetz (1967), Eckert (1979), and Field (1989) argue, open access regimes will be changed when the expected economic benefit of enclosing them exceeds the cost of creating and policing enclosures governed by systems of laws. Thus, with enclosure, a tract of ocean space is divided between two countries with each country gaining sovereign rights to its allocation. Both countries enjoy the full value of the resource rents available from their tracts - assuming proper economic management.

\footnotetext{
${ }^{1}$ Information kindly supplied through private communication by the International Boundaries Research Unit, Durham University, May, 2007.
} 
A half-way-house arrangement between not agreeing boundaries and sovereign rights behind 'lines in the sea' is that of a joint development zone (JDZ) whereby a pair of countries agree to share use of a resource - say, offshore oil, or marine fisheries. "JDZ" here is used as a generic term covering sharing agreements described variously as "provisional agreements", "provisional measures zones", "international fisheries committees" and "reciprocal fishing access" (Xue, 2005). Alternatively, Blake and Swarbrick (1998) also define four categories of JDZ as geological cooperation, whereby geologists determine the location of mineral deposits and national production quotas are allocated according to some boundary formula. Joint operations, whereby there is equal sharing of production regardless of which side of a theoretical boundary it occurs. For example, Germany-Netherlands share production in the Groningen gas field. United exploitation, where a single operator produces offshore oil and gas, and production is allocated according to some sharing formula; $90-10$ in some oil fields in the Timor Gap for example (King 2002). And, shared sovereignty, as between Saudi-Arabia and Sudan in the Red Sea.

Under UNCLOS (1982) Article 74, JDZs are legal entities governing ocean management in cases were boundaries of exclusive economic zones (EEZs) cannot be agreed between party states. ${ }^{2}$ In such cases, Article 123 of the Convention requires state parties to cooperate in marine conservation. ${ }^{3}$

${ }^{2}$ Article 74: Delimitation of the exclusive economic zone between states with opposite or adjacent coasts.

${ }^{3}$ Article 123: Cooperation of States bordering enclosed or semi-enclosed seas. 
By the mid-1990s only 15 offshore JDZs existed (Blake and Swarbrick, 1998). ${ }^{4}$ This small number may be surprising given that in agreeing to a JDZ a state does not necessarily relinquish its claim to sovereign rights. A claim is simply put on hold for possible resolution at a future date. Moreover, assuming that resource management under a JDZ arrangement improves on that of open access - for example improving fisheries management, economic rent can be expected to increase - even if it has to be shared with another country.

Over the last ten years the pace of formation of JDZ agreements seems to have been stepped up, especially in East Asia. Thus, China and Japan signed a joint fisheries agreement in 1997. China ratified JDZs with Vietnam in 2004 - a 15 year fisheries agreement in the Gulf of Tonkin; and with South Korea in 2000 for fisheries management - see Keyuan, 2005 and Xue, 2005. In 2005 China, Vietnam and Philippines signed the Tripartite Agreement for Joint Marine Seismic Undertaking in the Agreement Area in the South China Sea (Ministry of Foreign Affairs, Vietnam ${ }^{5}$ ).

If neither enclosure nor a JDZ are agreed the two countries concerned remain in dispute and efficient management of the relevant ocean tract remains impaired. As mentioned

\footnotetext{
${ }^{4}$ Examples of JDZs include the Australian-Indonesian 1989 Timor Gap Treaty; Australia-Papua New Guinea treaty (1978); Malaysia-Thailand treaties (1979 and 1990 Gulf of Thailand). Japan and South Korea formed a JDZ. Malaysia also has a JDZ with Vietnam (1993). In the Middle East there are JDZs between Saudi Arabia and Sudan and Saudi Arabia-Bahrain (1958). There is one between Qatar and UAE (1963). In Europe, France and Spain jointly exploit the Bay of Biscay (1973 agreement). Norway has a JDZ agreement with Iceland (1980) and another with the UK (1976). The UK has a JDZ with Argentina (1995).

${ }^{5}$ For information on this agreement see www.mofa.gov.vn/en/tt_baochi/pbnfn/ns050314164241
} 
before, it is impaired because with no agreed governing legal authority, management of external diseconomies prevalent with open access resources is not possible: fisheries management will be difficult if not impossible to institute; and oil companies will be reluctant to invest in offshore oil exploration while the legality of exploration, development and production rights remains questionable. As an illustration of oil company concerns about maritime boundaries consider the case of the Timor Gap. By 1978 Australia had granted petroleum leases in six areas of the Timor Sea. AquataineElf's Australian manager said "No one would want to find oil there without knowing who owns it. But we are not expecting any major problems because of the border lines already agreed to by Indonesia on either side of the disputed area. If these two lines are just joined together, there will be no trouble at all" (quoted King, 2002). Ironically, 30 years later the Timor Gap remains in dispute. Moreover, countries may have an economic inducement to use military power in the disputed area to protect their own producers who work there, e.g. warships accompanying fishing boats (see Bateman, 1998).

The rest of this paper continues as follows: Section II offers an economic analysis of the factors that approximately determine the choices that state level decision-makers make between moving to agreement on 'lines in the sea', agreeing to a JDZ or refusing to agree to either boundaries or to a JDZ. Woven into this analysis is empirical support for the assumptions used in the economic model. An attempt is made in Section III to explain in terms of the model the bargaining the tactics that bargainers have in fact adopted. Section IV concludes. 


\section{II: Economic Analysis}

Economic theory is used to explain three observed facts: widespread lack of agreement on maritime boundaries, fewness of JDZs, and the seemingly recent trend in some regions for maritime boundaries and joint development zones to be agreed. The analysis begins by asking the question what is the inducement to agree boundaries? The answer turns out to depend upon the expected net returns, or, resource rents, derived from drawing a seaward boundary between a pair of counties. To support this assumption it is clear that economic rent issues are present in the two linked agreements between China and Vietnam that delimit the Gulf of Tonkin and set fisheries management rules (Keyuan, 2005. ${ }^{6}$ Over-fishing problems were recognized by China when it introduced fishing effort reduction measures for its Gulf of Tonkin fishing fleet, for example, a closed season. However, both Vietnamese and Filipino fishers continued to fish so rendering the Chinese measures largely ineffective. The boundary agreement ends the former open access regime, enabling China to exclude foreign fishing boats. With offshore oil production in the area - already occurring in the Gulf of Tonkin (thought to contain a large amount of oil), the boundary agreement sets rules for the exploitation of offshore oil deposits that straddle the boundary.

Suppose a situation where two countries, A and B, dispute over which of two possible maritime boundary lines is to be drawn between them. One of four choices is open to each bargainer: agree on its preferred boundary, agree on the other country's preferred

\footnotetext{
${ }^{6}$ These are the Agreement on the Delimitation of the Territorial Sea, Exclusive Economic Zone and Continental Shelves in the Beibu Gulf and the Agreement on Fishery Cooperation in the Beibu Gulf, both ratified in 2004.
} 
boundary, agree a JDZ, or, agree neither boundaries nor a JDZ - so continuing the boundary dispute.

Also assume that the ranking of resource rents available to a country are highest with an agreed boundary, lower, but positive, with a JDZ, and least, assumed equal to zero, while a dispute continues. This ranking makes sense as resource rents, in principle, could be maximized when a sovereign has full independent management rights over a tract of ocean; lower when two sovereigns have to agree and probably compromise over management rules; and lowest with open access as no sovereign is able to impose a rational system of resource management.

Assuming no boundary has yet been drawn, a country will rationally not agree to a JDZ (with its lower economic rents) if expected resource rent from gaining sovereign rights behind a boundary exceed the cost of continuing a boundary dispute.

Thus,

$$
E(\text { resource.rent })=\sum_{t=1}^{T}\left(\frac{\left(p r_{t}(\$ r e n t)\right.}{(1+r)^{t}}-\frac{(1-p r)_{t} \$ 0_{t}}{(1+r)^{t}}\right)
$$

Where $E$ (resource rent) is the expected present value of resource rent, $p r_{t}$ is a decisionmaker's subjective probability of gaining sovereign rights in any given year $t=1 \ldots T, r$ is the decision-maker's rate of time preference, and \$rent is the annual rent that would be earned if sovereign rights where won. Note that $p r_{t}$ may change from year to year as can the rate of time preference, $r$, and value of annual rent. The probability of winning sovereign rights, $p r_{t}$, may change with circumstances - for example, if the other side's 
bargaining position is thought to have weakened $p r_{t}$ may increase. The rate of time preference, $r$, may increase if, for some reason, reaching an agreement is thought to have become more urgent. And annual resource rents may change for various reasons, for example, if newly gathered geological data indicates greater hydrocarbon deposits than previously envisaged. $^{7}$

If a boundary is not agreed, the boundary dispute continues. However, there is a cost of maintaining a dispute. The expected discounted present value of dispute cost is:

$$
E(\text { dispute. } \cos t)=\sum_{t=1}^{T}\left(\frac{(1-p r)_{t}(\$ \text { dispute } \cos t)_{t}}{(1+r)^{t}}\right)
$$

Where $(1-p r)_{\mathrm{t}}$ is the subjective probability of not having sovereign rights in year $\mathrm{t}$, in which case an annual dispute cost is incurred. These costs may be low - just the cost of a negotiating team. But they could be substantial - for example, as when warships have to accompany fishing boats or when actual military conflict breaks out. Or, dispute costs could be incurred outside of maritime issues as is implied by Van Dyke (2007), when he observes that Korea and Japan have an incentive to agree maritime boundaries so that they "can strengthen their relations in other areas and promote the mutual prosperity of their citizens" (page 205).

Similarly, with the case of China; Ziegler (2007) points out that China's recently adopted 'smile diplomacy' toward its neighbors is based on an economic calculus. Thus, "without

\footnotetext{
${ }^{7}$ Note that in equation (1) zero resource rent is assumed if the open access regime continues. Open access rents could be greater than zero, but still low compared with those derived through a management system.
} 
encouraging peace and prosperity around China's long borders there will be no peace and prosperity at home. And without peaceful development at home the Chinese Communist Party is toast" (page 7). He points out that for decades China maintained maritime border disputes (in addition to those on land) far from its coast line in the South China Sea that set it against Brunei, Malaysia, Philippines, Taiwan and Vietnam. But that now "China has applied balm to [these] old sores" (page 7). If this analysis is correct, China came in the last decade to realize that dispute cost over maritime boundaries was simply too high.

The net advantage of continuing a boundary dispute (no boundary, no JDZ) is

(3) $E(\underline{\text { net }}$ resource rent $)=E($ resource rent $)-E($ dispute cost $)$

Or,

$$
E(N R R)=(\text { equation } 1)-(\text { equation } 2)
$$

The payoffs in figure 1 represent the present value of expected net resource rent, $\mathrm{E}(\mathrm{NRR})$, defined in equations (3) or (4) as the probability weighted resource rent expected from a given tract of disputed ocean less the cost of continuing the dispute with the other party. The payoffs in the lower left of each box are those for country A, those in the upper right for country B. E(NRR) is used in our analysis of whether a pair of countries will agree a marine boundary, a JDZ, or, will continue disputing sovereign rights over a particular ocean tract. 


\begin{tabular}{|c|c|c|}
\hline & $\mathrm{COL}$ & \\
\hline & Enclosure & JDZ \\
\hline & $\mathrm{E}(\mathrm{NRR})>0$ & $<0$ \\
\hline EIICIOsure & Dispute continues & Line favors country $A$ \\
\hline COUNTRY A & $\mathrm{E}(\mathrm{NRR})>0$ & $>0$ \\
\hline & $>0$ & $<0$ \\
\hline Joint & Line favors country B & JDZ formed \\
\hline Zone & $<0$ & $<0$ \\
\hline
\end{tabular}

Figure 1: Ocean boundaries strategies and net expected payoffs

Note that 'resource rent' is the annual return to a country above costs of production. 'Resource rent' in this sense is different to E(NRR) as the latter includes a probability weighted component (equation (1)) as well as the expected value of future dispute costs (equation (2)).

Figure 1 is used the following way. If $\mathrm{E}(\mathrm{NRR})$ is positive for both countries each country will settle for nothing less than its preferred maritime boundary because dispute cost is low relative to the expected resource rents that may be garnered behind that particular boundary. Thus, in the northwest box the boundary dispute will continue. 
Now suppose that $E(N R R)$ is positive for one side but negative for the other party. This situation favors agreement on the boundary favored by the 'positive' side. Thus, in the northeast box, $\mathrm{E}(\mathrm{NRR})$ is positive for country $\mathrm{A}$, so it will continue to insist on its favored boundary, but negative for country B. In terms of our economic model, country B has no incentive to prolong the boundary dispute, and it will agree to the boundary preferred by country A. Country B thereby avoids future dispute costs but still gains some increase in resource rent, though not as much of an increase had the boundary been drawn on its terms.

If the signs of $\mathrm{E}(\mathrm{NRR})$ are reversed, negative for country $\mathrm{A}$ and positive for country $\mathrm{B}$, we move to the southwest box in Figure 1. In this situation the boundary favored by country B will be agreed. Country A sees both a negative return from continuing to pursue its favored boundary and some increase in its resource rents behind the boundary favored by country B.

Finally, in the southeast box E(NRR) is negative for both state parties. In this case both countries would want to abandon insistence on their particular favored maritime boundary because of the relatively high dispute costs. This situation is ripe for the compromise of a JDZ as both state parties can postpone the boundary issue while enjoying increased resource rents derived through more efficient management of the ocean tract in dispute. Another possibility is that the state parties agree on a compromise boundary, but this does lose the degree of freedom of reopening boundary negotiations within the JDZ framework. Even so, agreement on a JDZ is not necessarily 
straightforward because the state parties may continue to dispute over shares in resource rents.

Section III: Strategies for reaching agreement on marine boundaries

Staring from the northwest box in Figure 1 - where a dispute remains unresolved, either state party has an incentive to take actions to raise the other side's dispute costs, without at the same time raising its own. If successful, depending on which country's dispute cost increases, movement may be either to the northeast or southwest boxes where boundary agreement is on the terms of the 'positive' side country. Should both countries be successful in raising the other country's dispute costs, movement may be to the southeast box where a JDZ may be agreed.

What actions might a country take? Answers may be found by inspecting the formula for $\mathrm{E}(\mathrm{NRR})$ - equation (3).

1. "Play for time" - stonewall - making sure that the other side knows that a boundary is unlikely to be agreed for many years into the future. If successful this reduces $p r_{t}$ and increases $T$ in equation (1) - so reducing $E$ (resource rent) and raising the value of equation (2), the expected cost of maintaining the dispute. But as delay reduces expected resource rents of both countries, this strategy is feasible only for the country with the lower rate of time preference - in which case its expected resource rent falls least. 
2. "Agitate", for example, take the other country to the International Court of Justice, or, argue for an international adjudicator, or purse the other country in the civil courts for compensation - all tactics used by East Timor in its dispute with Australia (King, 2002). Such tactics raise the expected cost of continuing the dispute for the "positive side' - equation (2) becomes larger.

3. "Appeal to the international community" - point out the unfairness of the other side insisting on its preferred demarcation line rather than their own or a JDZ. An example of this is again (poor) East Timor's complaint against (rich) Australia that the latter will not agree to 'fair' maritime boundaries (specifically the end points of the Indonesia-Australia line of demarcation agreed in their 1972 Treaty that, according to East Timor, impinge into East Timor's waters). Such an appeal might be effective if the rich country did not want to lose face in the international community (perhaps impairing its credentials as a good foreign aid giver). A successful appeal inducing the other side to settle on a JDZ - would in effect raise the rate of time preference - the discount rate applied to expected resource rents.

4. Raise the other side's dispute costs by other means as, for example, in 2006 in the Spratly Islands marine boundary dispute between Vietnam and Taiwan. Vietnam is reported to have permitted strikes against Taiwanese firms as a counter-measure against Taiwan's failure to agree a boundary. ${ }^{8}$

\section{Section IV: Conclusions}

This paper has offered a general economic framework in which state party bargaining strategies over agreeing lines in the ocean and related behaviors are readily understood.

${ }^{8}$ The Economist, January $28^{\text {th }}, 2006$. 
The economic model takes into account both resource rents expected from a disputed tract of ocean space as well as the expected dispute costs incurred in accessing those resource rents. It is hypothesized that differences between state parties in dispute costs can significantly influence the outcome of bargaining over which lines in the ocean will be drawn if, indeed, they are drawn. When expected resource rents are high relative to dispute cost a state party will continue to insist on its preferred maritime boundary. When this is true for both state bargainers (in a bilateral game) the prospect for agreement on a maritime boundary is dim. However, should one state party incur high dispute costs relative to expected resource rents, it is quite likely to agree on the boundary favored by the other country. Finally, when dispute costs are high for both bargainers, each will be open to abandoning its claimed boundary and agreeing on the temporary measure of a joint development zone. A JDZ has the advantages of reducing dispute costs and increasing expected resource rents, while leaving open for future negotiation sovereign rights issues. It is also recognized that a state party not coming to a boundary agreement has incentives to take actions aimed at weakening the bargaining position of the other party. These actions are identified as specifically raising the dispute cost of the other party. Empirical evidence is brought to bear supporting the assumptions underlying the foregoing analysis. Some of this evidence relates to East Asian waters, especially to China and the several countries in which it is in maritime boundary dispute. It is argued that China's recent willingness to create JDZ's with its neighbors is largely explained by China's perceived rise in dispute costs. 


\section{References}

Bateman, S. (1998), "Economic Growth, Marine Resources and Naval Arms in East Asia - A Deadly Triangle?", Marine Policy, 23 (4-5), 297-306.

Blake, G. H., Pratt, M. A., Schofield, C. H., and Allison Brown, J., (1998), Boundaries and Energy: Problems and Prospects, Editors, Springer

Blake, G.H. and Swarbrick, R.E. (1998), "Hydrocarbons and International Boundaries: A Global Overview", in Blake and Pratt, op. cit.

Demsetz, H. (1967), "Towards and theory of property rights", American Economic Review Papers \& Proceedings, 56 (2), pp 347-59.

Eckert, R.D (1979), The Enclosure of Ocean Resources, Hoover Institution

Field, B (1989), "The evolution of property rights", Kyklos, 47 (3), 319-45.

King, R. J. (2002), “The Timor Gap, 1972-2002, http://www.aph.gov.au/house/committee/jsct/timor/subs/sub43.pdf of Justice.

Keyuan, Z. (2005), "The Sino-Vietnamese Agreement on Maritime Boundary Delimitation in the Gulf of Tonkin", Ocean Development and International Law, 36, 13-24.

Myers, R.A. and Worm, B. (2003), "Rapid Worldwide Depletion of Predatory Fish Communities", Nature, 423, 15th May, 280-83

Xue, G. (2005), Bilateral Fisheries Agreements for the Cooperative Management of the Shared Resources of the China Seas: A Note", Ocean Development and International Law", 36, 363-74.

Zielger, D. (2007), "Smile Diplomacy: Working Magic along China's Periphery”, in "Reaching for a Renaissance", The Economist Special Report, March $31^{\text {st }}$. 